\title{
Bacterial killing in vitro by abscess-derived neutrophils
}

\author{
J. J. FINLAY-JONES, P. H. HART, L. K. SPENCER, M. F. NULSEN, * P. A. KENNY \\ and P.J.McDONALD
}

Department of Clinical Microbiology, School of Medicine, Flinders University of South Australia, GPO Box 2100 , Adelaide, S.A., 5001, Australia

\begin{abstract}
Summary. In the absence of antimicrobial therapy, bacteria such as Bacteroides fragilis, Escherichia coli and Proteus mirabilis may persist within an intra-abdominal abscess in the presence of large numbers of neutrophils which, under optimal conditions in vitro, can readily phagocytose and kill the same bacterial strains. Neutrophils taken from abscesses induced by gram-negative bacteria such as those above contain viable organisms. On incubation in vitro in the presence of serum, these neutrophils kill the bacteria phagocytosed in the abscess poorly, if at all, yet can readily kill organisms added in vitro. To determine possible mechanisms that might explain this, we examined the bactericidal activity in vitro of neutrophils from a range of abscesses induced by one or two species of bacteria plus an abscess-potentiating agent, bran. The organisms studied were $B$. fragilis, E. coli, $P$. mirabilis and Staphylococcus aureus. The killing in vitro of $E$. coli and $P$. mirabilis, engulfed within an abscess, was significantly less than that of the same organisms when they were added to the in-vitro assay. In contrast, the killing of $S$. aureus was similar, whether engulfed in vivo or in vitro. However, $S$. aureus was less susceptible to phagocytosis and killing in vitro than $P$. mirabilis or E. coli, and the killing of $S$. aureus during in-vitro incubation of neutrophils that had engulfed the organism within the abscess was similar to that of the gram-negative bacteria engulfed within the abscess. We examined whether organisms phagocytosed in vivo were within neutrophils which had diminished or no expression of cell surface Fc and C3 receptors, and might, therefore, be unresponsive to extracellular serum factors such as complement which stimulate intracellular killing. No population of neutrophils lacking CR3 complement receptors was detected. Furthermore, the expression of these receptors was enhanced on abscess neutrophils compared with peripheral blood neutrophils. Fc $\gamma$ RII receptor expression was equivalent in the two populations. Extracellular serum was necessary for any abscess neutrophil bactericidal activity. To determine whether the bacteria within abscess neutrophils were a subpopulation selected for resistance to intracellular killing, we lysed the neutrophils and added the released bacteria to bactericidal assays with peritoneal exudate neutrophils. The bacteria were killed readily, but not as efficiently as log-phase organisms grown in vitro. As these studies have shown that neutrophils from abscesses are functional, with enhanced CR3 expression, and that bacteria persisting within abscesses are not resistant to intracellular killing, it is possible that the poor killing in vitro of bacteria engulfed in vivo by abscess neutrophils reflects depleted intracellular killing mechanisms in those particular neutrophils, or results from the phagocytosis of organisms under conditions prevailing within abscesses, or is due to as yet undefined bacterial virulence factors.
\end{abstract}

\section{Introduction}

Surgical wound infection and intra-abdominal abscess formation are potential complications of intraabdominal surgery. Infecting organisms are typically those found as normal flora of the gastrointestinal tract and vagina. Obligately anaerobic bacteria are found in most intra-abdominal abscesses, and, of the four to five species usually isolated from adequately

Received 27 April 1990; accepted 27 June 1990.

Present address: Department of Microbiology and Genetics, Massey University, Palmerston North, New Zealand. collected specimens, it is the obligate anaerobes which predominate. $^{1}$

Experimental models of intra-abdominal abscess formation have typically employed the anaerobe Bacteroides fragilis, with or without an accompanying facultative intestinal organism such as Escherichia coli. The predominance of such organisms in clinical specimens, ${ }^{1}$ and the findings that these organisms are synergic in the production of sepsis in experimental models, ${ }^{2,3}$ have led to hypotheses and experiments aimed at investigating possible mechanisms. It was suggested ${ }^{3}$ that the facultative organism(s) may reduce 
the redox potential and oxygen tension to allow the anaerobes to proliferate. A role for the anaerobes in the synergy was suggested by Ingham et al. ${ }^{4}$ who found that high concentrations of anaerobes, including B. fragilis, can inhibit phagocytic killing by neutrophils. Superimposed on these hypotheses is the finding that the production of abscesses requires the inoculation of a "potentiating agent" such as bran, ${ }^{2}$ or autoclaved colonic contents plus barium sulphate. ${ }^{3}$

Our studies on the pathogenesis of anaerobic infection have addressed the apparent paradox that abscesses with viable organisms can persist in infected mice $^{2}$ in spite of what appears to be an excess of neutrophils at the site of infection, and the susceptibility of the infecting organisms to phagocytic killing by neutrophils in vitro. We obtained viable neutrophils from abscesses, incubated them in vitro with serum under aerobic conditions, with or without additional bacteria, and monitored the change in viability of the bacteria that had been phagocytosed in vivo, and of those that had been introduced in vitro. ${ }^{5}$ We noted that neutrophils from abscesses induced by pairs of organisms selected from $\boldsymbol{B}$. fragilis, $E$. coli and Proteus mirabilis did not kill the facultative organisms as efficiently as they killed similar organisms introduced in vitro, but that neutrophils from $S$. aureus abscesses killed the intracellular organisms on subsequent in vitro incubation as efficiently as they killed similar organisms added to the in-vitro assay. Nevertheless, the killing of any organism that had been phagocytosed in vivo was less than one log value (90\%) over the 90 min assay. Furthermore, abscess-derived neutrophils were less efficient at killing bacteria added in vitro than neutrophils from peripheral blood or peritoneal exudate of abscess-bearing mice. In this paper, we present further data on the activities of neutrophils from monomicrobial abscesses as well as those induced by pairs of bacterial species, and determine whether the organisms within abscess-derived neutrophils represent a subpopulation selected for resistance to intracellular killing. We also present evidence of the expression of receptors CR3 and Fc $\gamma$ RII on neutrophils from abscesses, peritoneal exudate and peripheral blood, and that in-vitro killing of organisms phagocytosed in vivo, if demonstrable, requires the presence of serum.

\section{Materials and methods}

\section{Mice}

Male mice of the BALB/c strain, aged 8-12 weeks, were obtained from the Animal Resource Centre of the Department of Agriculture, South Australia. Experiments were performed according to the ethical guidelines of the National Health and Medical Research Council, the Commonwealth Scientific and Industrial Research Organisation, and the Australian Agricultural Council.

\section{Bacteria}

E. coli, $P$. mirabilis and $B$. fragilis strains were isolated from abscesses of BALB/c mice inoculated intraperitoneally 10 days previously with colonic and caecal contents of meat-fed mice. ${ }^{2}$ The strain of $S$. aureus was a clinical isolate. Bacteria were stored at $-70^{\circ} \mathrm{C}$ as previously described. ${ }^{2}$ For induction of abscesses, frozen stocks were diluted as required. For the bactericidal assays, small amounts of frozen stock cultures of $E$. coli, P. mirabilis, and $S$. aureus were grown aerobically overnight at $37^{\circ} \mathrm{C}$ in TrypticaseSoy Broth (TSB; Difco). Small samples of these suspensions were inoculated into fresh TSB. After incubation for 3-4 h, the log-phase bacteria were harvested and washed with saline $0.9 \%$ before resuspension at $1 \times 10^{9} \mathrm{cfu} / \mathrm{ml}$ in $10 \mathrm{~mm}$ Hepes-buffered RPMI 1640 medium, pH 7.2 (RPMI; Flow Laboratories, McLean, VA, USA). The viable count was assessed by comparing absorbance at $420 \mathrm{~nm}$ with standard curves. ${ }^{6}$

\section{Serum}

The preparation of normal mouse serum (NMS) has been described previously. ${ }^{6}$

\section{Opsonisation of bacteria}

Bacteria $\left(1 \times 10^{9} \mathrm{cfu}\right)$ suspended in $1 \mathrm{ml}$ of RPMI were incubated with an equal volume of normal mouse serum for $30 \mathrm{~min}$ at $37^{\circ} \mathrm{C}$ in a shaking water bath. Bacteria were washed twice with saline $0.9 \%$ before incubation with phagocytic cells.

\section{Intra-abdominal abscess induction}

Abscesses were induced by the method of Nulsen $e t$ $a .^{2}$ Each mouse was given an intraperitoneal injection of bacteria with $1 \mathrm{mg}$ of bran as the abscesspotentiating agent in a total volume of $0.05 \mathrm{ml}$ of RPMI. For induction of abscesses containing a single species of gram-negative bacteria ( $P$. mirabilis or $E$. coli), $2 \times 10^{7}$ cfu were injected. For $S$. aureus abscesses, $(1-2) \times 10^{7} \mathrm{cfu}$ were injected. For induction of abscesses with bacterial pairs, the following inocula were used: B. fragilis, $5 \times 10^{8} \mathrm{cfu} ; E$. coli, $P$. mirabilis and $S$. aureus, $(3-5) \times 10^{7} \mathrm{cfu}$. After 6 days, the functional activities of neutrophils harvested from abscesses were examined. Inoculation of $1 \mathrm{mg}$ of bran alone does not induce detectable intraperitoneal abscesses; the minute sterile lesions that arise are comprised mainly of mononuclear cells. ${ }^{2}$

\section{Isolation of leucocytes from abscesses}

Mice were killed by cervical dislocation and intraabdominal abscesses were excised. After mechanical teasing, abscess slurries were diluted in mouse osmolality phosphate-buffered saline (MPBS) ${ }^{7}$ and stirred 
at $37^{\circ} \mathrm{C}$ for $10 \mathrm{~min}$. The supernate was harvested and the slurry was incubated and stirred twice more with MPBS for $10 \mathrm{~min}$. The cells in the supernate were pelleted by centrifugation at $175 \mathrm{~g}$ for $8 \mathrm{~min}$, pooled, resuspended in Hanks's Balanced Salts Solution (HBSS; Commonwealth Serum Laboratories, Melbourne, Australia) buffered with $10 \mathrm{~mm}$ Hepes, and loaded onto Percoll density gradients.

\section{Isolation of bacteria from abscesses}

Abscesses were disaggregated as described in the previous paragraph. To obtain non-cell-associated (extracellular) bacteria, the cells and coarse debris in the suspension were pelleted by centrifugation at $175 \mathrm{~g}$ for $8 \mathrm{~min}$, the supernates were harvested and then centrifuged at $1700 \mathrm{~g}$ for $15 \mathrm{~min}$ to pellet bacteria. To obtain intracellular bacteria, neutrophils from abscesses were lysed by sonication for $20 \mathrm{~s}$ (Sonicator Model W-375, Ultrasonics Inc., Plainview, NY, USA) or by treatment with $20 \times$ their volume of Triton X$1000.05 \%$ in saline $0.9 \%$ for $20 \mathrm{~min}$. Cell debris was removed by centrifugation at $175 \mathrm{~g}$ for $8 \mathrm{~min}$, and the pellet was washed once in saline $0.9 \%$. Bacteria were obtained from these supernates by centrifugation at $1700 \mathrm{~g}$ for $15 \mathrm{~min}$.

\section{Percoll solutions}

Solutions of Percoll (Pharmacia Fine Chemicals AB, Uppsala, Sweden) were prepared as described previously. ${ }^{8}$ Briefly, nine volumes of Percoll were mixed with one volume of $10 \times$ concentrated $\mathrm{Ca}^{++}$ and $\mathrm{Mg}^{++}$- free $\mathrm{HBSS}$ before dilution to the required working densities with single-strength $\mathrm{HBSS}, \mathrm{Ca}^{++}$and $\mathrm{Mg}^{++}$-free, $\mathrm{pH} 7 \cdot 2$, supplemented with $10 \mathrm{mM}$ Hepes. The following equation ${ }^{9}$ was used to calculate the mixing ratios:

$$
\begin{aligned}
& \text { density }(\mathrm{g} / \mathrm{ml})= \\
& \quad[\text { concentration }(\%) \text { of Percoll stock solution } \\
& \times 0.001186]+1.0041 .
\end{aligned}
$$

The Percoll solution was diluted to working solutions of $70 \%$ and $45 \%$ concentration. These solutions were of density 1.0871 and $1.0575 \mathrm{~g} / \mathrm{ml}$ respectively.

\section{Density gradient centrifugation of the abscess leucocyte suspensions}

Pre-formed gradients were prepared in polycarbonate $100 \times 16 \mathrm{~mm}$ tubes (Disposable Products, Adelaide, South Australia). Pasteur pipettes were used to layer $3 \mathrm{ml}$ of the Percoll $45 \%$ solution on to $3 \mathrm{ml}$ of the $70 \%$ solution. The cell suspension diluted in HBSS was layered on top of the gradient. Approximately $5 \times$ $10^{7}$ cells were loaded onto each gradient. Tubes were centrifuged at $1600 \mathrm{~g}$ for $30 \mathrm{~min}$ at $10^{\circ} \mathrm{C}$ (IEC PR 6000 centrifuge; Div. Damon Corp., Needham Heights, MA, USA) and the cell band above the Percoll 70\% solution was harvested. These cells were washed twice with MPBS ( $\left.175 \mathrm{~g}, 8 \mathrm{~min}, 4^{\circ} \mathrm{C}\right)$ before resuspension in RPMI 1640 medium. The abscess cells were recovered in two discrete fractions-the first at the interface between Percoll-free medium and the Percoll solution of density $1.0575 \mathrm{~g} / \mathrm{ml}$, the second between Percoll solutions of density 1.0575 and $1.0871 \mathrm{~g} / \mathrm{ml}$. After Percoll gradient fractionation of four different abscess cell preparations, a mean of $55 \%$ (range $42-72 \%$ ) of recovered cells was present in the band of greater density. These cells were always greater than $95 \%$ viable by trypan blue exclusion, and they contained 93 (SD 1)\% neutrophils. The cells of density less than $1.0575 \mathrm{~g} / \mathrm{ml}$ were 58 (SD 9) $\%$ viable and were identified as 82 (SD 9)\% neutrophils. The functional activities of only those cells banding between densities 1.0575 and $1.0871 \mathrm{~g} / \mathrm{ml}$ were further investigated.

\section{Isolation of peritoneal exudate leucocytes and neutrophil enrichment on Percoll density gradients}

Peritoneal leucocytes were isolated as described previously. ${ }^{8,10}$ Briefly, mice were inoculated with $1 \mathrm{ml}$ of Brain Heart Infusion Broth (Oxoid). After $3.5 \mathrm{~h}$, the mice were killed by cervical dislocation and their peritoneal cavities were washed out with $5 \mathrm{ml}$, then $3 \mathrm{ml}$, of cold MPBS. The cells were pelleted and washed before suspension in HBSS and layering on to gradients prepared with Percoll solutions of $81 \%, 65 \%$ and $55 \%$ diluted with single-strength $\mathrm{HBSS}, \mathrm{Ca}^{++}$

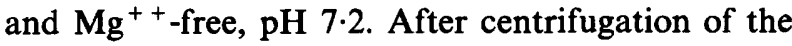
gradients as described above, the cells banding between the solutions of greatest density (1.0812 and $1 \cdot 1002 \mathrm{~g} / \mathrm{ml}$ ) were harvested, washed twice, and resuspended in RPMI 1640 medium. These cells were greater than $98 \%$ viable and greater than $97 \%$ neutrophils. ${ }^{10}$

\section{Isolation of leucocytes from peripheral blood, and neutrophil enrichment on Percoll density gradients}

As described previously for abscess-bearing mice, ${ }^{5}$ blood from the retro-orbital venous plexus of anaesthetised normal mice was collected into lithium-heparin tubes (Kayline, South Australia) and diluted approximately 10-fold with MPBS before centrifugation (175 g $20 \mathrm{~min}, 4^{\circ} \mathrm{C}$ ). After removal of the supernates, $9 \mathrm{ml}$ of distilled water was added to each of the pellets. The tubes were inverted 10 times and $1 \mathrm{ml}$ of $10 \times$ concentrated HBSS was added. After further mixing, the tubes were filled with an approximately equal volume of MPBS. After centrifugation and removal of the supernate, erythrocyte lysis was repeated. The cells remaining were washed one further time before loading on to pre-formed Percoll density gradients. These gradients were formed from $3 \mathrm{ml}$ each of Percoll solutions of density $1.1002,1.0693$ and $1.0575 \mathrm{~g} / \mathrm{ml}$ (i.e., $81 \%, 55 \%$ and $45 \%$ solutions) respectively. After centrifugation at $1600 \mathrm{~g}$ for $30 \mathrm{~min}$ at $10^{\circ} \mathrm{C}$ (as above), 
the cells banding between densities $1 \cdot 1002$ and 1.0693 $\mathrm{g} / \mathrm{ml}$ were washed twice with MPBS and resuspended in RPMI 1640 medium.

\section{In-vitro assay for killing of intracellular bacteria phagocytosed in vivo}

Abscess-derived neutrophils $\left(5 \times 10^{6}\right)$ were resuspended in $0.9 \mathrm{ml}$ of RPMI 1640 medium, $\mathrm{pH} 7.2$, buffered with $10 \mathrm{mM}$ Hepes in $90 \times 13 \mathrm{~mm}$ polycarbonate tubes (Disposable Products) and placed on ice. NMS $(0.1 \mathrm{ml})$, or RPMI 1640 medium as a control, were added, $0.05-\mathrm{ml}$ samples were taken, and the tubes were incubated at $37^{\circ} \mathrm{C}$ for $90 \mathrm{~min}$. Incubation was on an angled platform rotating at $20 \mathrm{rpm}$ (Nutator; Clay-Adams, Becton Dickinson and Co., Parsippany, NJ, USA). Further samples for quantitation of bacterial concentrations were withdrawn after incubation for 45 and $90 \mathrm{~min}$ at $37^{\circ} \mathrm{C}$. Samples of $0.05 \mathrm{ml}$ were added to $5 \mathrm{ml}$ (or, infrequently, $0 \cdot 1-\mathrm{ml}$ samples to $0.9 \mathrm{ml}$ ) of Triton X-100 (Ajax Chemicals, Sydney, Australia) $0.05 \%$ in saline $0.9 \%$ at room temperature and vortex mixed to aid the lysis of leucocytes. After further 10 -fold dilution in saline, $0 \cdot 1-\mathrm{ml}$ volumes were spread on blood agar or Cystine-Lactose-ElectrolyteDeficient Agar (Oxoid), and colonies were counted after incubation overnight at $37^{\circ} \mathrm{C}$. The change in the count of viable bacteria, as estimated by the numbers of colonies formed, was calculated as follows:

$$
\begin{aligned}
\Delta \log _{10}(\mathrm{cfu} / \mathrm{ml}) & =\left[\log _{10}(\mathrm{cfu} / \mathrm{ml}) \text { at time } \mathrm{t}\right] \\
& -\left[\log _{10}(\mathrm{cfu} / \mathrm{ml}) \text { at time } 0\right] .
\end{aligned}
$$

The change in the number of viable bacteria during the 90-min incubation period was also expressed as a percentage change in the number of bacteria measured in samples taken at the start of the assay. At the start of the incubation at $37^{\circ} \mathrm{C}, 0.05-\mathrm{ml}$ samples were taken for the preparation of cytocentrifuge smears, JennerGiemsa staining, and determination by light microscopy of cell morphology and percentage of neutrophils with associated bacteria.

\section{Bactericidal assay}

The assay was similar to that described previously. ${ }^{8,10}$ Briefly, the assay mixture consisted of $5 \times 10^{6}$ abscess or peritoneal exudate leucocytes with $1 \times 10^{7}$ opsonised bacteria and NMS $2 \%$ in a final volume of $1 \mathrm{ml}$ of RPMI. The bacteria had been opsonised in NMS $50 \%$ before washing and addition to the assay. Incubation was at $37^{\circ} \mathrm{C}$ on a platform rotating at $20 \mathrm{rpm}$. Samples of $0.05 \mathrm{ml}$ (or $0.1 \mathrm{ml}$ ) were withdrawn after incubation for 0,45 , and $90 \mathrm{~min}$, and changes in viable bacterial concentrations were determined as above.

\section{Monoclonal antibodies (MAbs)}

The three MAbs used were of rat origin and of the IgG2b subclass:
(1) $M A b 2.4 G 2$, which binds to the Fc receptor for IgG1, IgG2a and IgG2b on mouse neutrophils. ${ }^{11,12}$ The supernate of the hybridoma cells cultured in vitro was used as the source of MAb.

(2) $M A B$ NIMP-R10, which binds to complement receptor 3 (CR3) on mouse neutrophils. ${ }^{13}$ NIMP-R10 was derived from the fusion of spleen cells from a LOU rat immunised with purified preparations of mouse eosinophils, and the rat myeloma 210RCY3Ag123. ${ }^{13}$ An antibody-rich preparation obtained from the ascitic fluid of rats inoculated intraperitoneally with the hybridoma cells was used.

(3) $M A b M 1 / 70$, which was raised against mouse macrophages and binds to mouse CR3, and to human CR3 ${ }^{14}$ Hybridoma cells M1/70.15.11.5 were obtained from the American Type Culture Collection (ATCC TIB 128), and the supernates from cultures were harvested for use.

The preparations of MAb, diluted 1 in 2 or 1 in 3, were dialysed extensively against MPBS before dilution with RPMI 1640 and filtering $(0 \cdot 22 \mu \mathrm{m})$. Before incubation of MAb with cells, the MAb solutions were ultracentrifuged $\left(150000 \mathrm{~g}, 15 \mathrm{~min}, 4^{\circ} \mathrm{C}^{11}\right)$. The dilutions of the MAb used were chosen to ensure maximal levels of binding to mouse neutrophils. ${ }^{10} \mathrm{The}$ anti-Fc $\gamma$ RII MAb 2.4 G2 and the anti-CR3 MAb M1/ 70 were used at a final concentration of 1 in 10 , and the NIMP-R 10 at 1 in 100.

\section{Assay of Fc $\gamma$ RII and $C R 3$ expression}

Leucocytes (neutrophil-enriched bands from Percoll density gradient centrifugation) $5 \times 10^{6}$ in a volume of $0 \cdot 15-0.25 \mathrm{ml}$ RPMI 1640 were incubated with $0.3 \mathrm{ml}$ of the appropriately diluted MAb, with shaking, at $4^{\circ} \mathrm{C}$ for $20 \mathrm{~min}$. After washing with MPBS containing azide $0.02 \%$, the pelleted cells were resuspended in $0.3 \mathrm{ml}$ of FITC-labelled rabbit anti-rat IgG (Nordic, Tilburg, The Netherlands) diluted 1 in 50 with MPBS containing azide $0.02 \%$. After further mixing for 20 $\min$ at $4^{\circ} \mathrm{C}$, the cells were washed and resuspended at a concentration of $2-3 \times 10^{6} / \mathrm{ml}$ in MPBS with azide $0.02 \%$. Fluorescence profiles were determined by flow cytometry with a FACS IV (Becton-Dickinson, Mountain View, CA, USA). Cells deemed to be other than neutrophils on the 90-degree light scatter were excluded from the fluorescence profiles. The modal fluorescence intensity for each population examined was selected as the parameter to compare receptor expression amongst different populations, with measurements made on a linear scale and corrected for gain setting.

\section{Expression of results}

Mean values \pm 1 SD for $n$ observations have been presented. The significance of differences was assessed by use of a two-tailed Student's $t$-test. 


\section{Results}

\section{Killing of bacteria engulfed in vivo and in vitro by abscess-derived neutrophils}

We have established previously ${ }^{5}$ that neutrophils from abscesses induced by $E$. coli $+B$. fragilis, $P$. mirabilis $+B$. fragilis, or $E$. coli $+P$. mirabilis kill the facultative bacteria on subsequent incubation in vitro in the presence of serum much less effectively than they could kill similar organisms that they engulfed in vitro. In contrast, neutrophils from $S$. aureus abscesses killed $S$. aureus engulfed in vivo as efficiently as they killed $S$. aureus added in vitro. Therefore, we tested neutrophils from a larger range of abscesses involving S. aureus, E. coli or P. mirabilis alone, or pairs of these, or one of these with $B$. fragilis, and compared the killing of the facultative organism engulfed in vivo with that of the same organism added in vitro.

The leucocyte:viable bacterium ratios for the organisms that had been engulfed in the abscesses ranged from 4:1 to $170: 1$ (table I). The organisms added in vitro were in the ratio of 1 neutrophil to 2 bacteria. For abscesses that involved $E$. coli or $P$. mirabilis, the intracellular killing of those organisms that had been engulfed in vivo was significantly less than that of the same organisms added in vitro (table II). In contrast, for abscesses associated with S. aureus, with or without other organisms, the intracellular killing of $S$. aureus engulfed in the abscess was similar to that of the same organism added in vitro, although the intracellular killing of the gram-positive organism engulfed in vivo was of a similar magnitude to that of the gramnegative organisms engulfed in vivo (table II). The data also indicated that the susceptibility of $P$. mirabilis to phagocytosis and killing in vitro by abscess neutrophils was greater than that of $E$. coli, which itself was more susceptible than $S$. aureus.

\section{Susceptibility of bacteria isolated directly from abscesses to killing by neutrophils}

In view of the findings that the gram-negative organisms engulfed in vivo were killed less efficiently than other gram-negative bacteria introduced in vitro, it was possible that the organisms engulfed in vivo and present intracellularly represented a population of bacteria that were refractory to intracellular killing. Therefore, we examined abscess-derived bacteria to determine whether they were susceptible to neutrophil bactericidal activity. Two populations of abscessderived bacteria (extracellular and cell-associated) were isolated, and their susceptibility to killing by neutrophils determined in two separate experiments. From an E. coli $+B$. fragilis abscess, $22 \%$ of bacteria recovered were cell-associated; from a $P$. mirabilis + $B$. fragilis abscess, $40 \%$ of organisms were cellassociated.

Both extracellular and cell-associated, abscessderived $P$. mirabilis, isolated directly without subculture from $P$. mirabilis $+B$. fragilis abscesses, were susceptible to killing by peritoneal exudate neutrophils in aerobic conditions in the presence of serum (table III). In a similar experiment, $E$. coli from an $E$. coli + $B$. fragilis abscess was susceptible to killing by peritoneal exudate neutrophils (table III). Killing was less than that noted for log-phase organisms taken from broth cultures. In experiments reported in table III, the intracellular bacteria were obtained by sonication to disrupt leucocytes. Intracellular bacteria released by the detergent Triton X100 were variable in their susceptibility to the bactericidal activities of peritoneal exudate neutrophils. However, about $50 \%$ of intracellular bacteria were killed in the preparation of the bacterial suspensions with the detergent, suggesting they were less suitable for study than bacteria released by sonication.

Table I. Intracellular bacterial concentrations in abscess-derived neutrophils

\begin{tabular}{|c|c|c|c|}
\hline Abscess induced by & $\begin{array}{c}\text { Organism examined } \\
\text { (number of experiments) }\end{array}$ & $\begin{array}{l}\text { Concentration }{ }^{*} \text { of } \\
\text { bacteria }\end{array}$ & $\begin{array}{l}\text { Ratio (leucocytes: } \\
\text { viable bacteria) }\end{array}$ \\
\hline $\begin{array}{l}P . \text { mirabilis } \\
P . \text { mirabilis }+B . \text { fragilis } \\
P . \text { mirabilis }+E . \text { coli } \\
P . \text { mirabilis }+S . \text { aureus }\end{array}$ & $\begin{array}{l}P . \text { mirabilis }(4) \\
P . \text { mirabilis }(4) \\
P . \text { mirabilis }(6) \\
P . \text { mirabilis (5) }\end{array}$ & $\begin{array}{l}5.0 \times 10^{4} \\
3.0 \times 10^{4} \\
3.8 \times 10^{4} \\
3.5 \times 10^{4}\end{array}$ & $\begin{array}{l}100: 1 \\
170: 1 \\
133: 1 \\
141: 1\end{array}$ \\
\hline $\begin{array}{l}E . \text { coli } \\
E . \text { coli }+B . \text { fragilis } \\
E . \text { coli }+P . \text { mirabilis } \\
E . \text { coli }+S . \text { aureus }\end{array}$ & $\begin{array}{l}E . \operatorname{coli}(4) \\
E . \operatorname{coli}(6) \\
E . \operatorname{coli}(6) \\
E . \operatorname{coli}(5)\end{array}$ & $\begin{array}{l}2.6 \times 10^{5} \\
1.2 \times 10^{5} \\
2.4 \times 10^{5} \\
3.5 \times 10^{4}\end{array}$ & $\begin{array}{r}20: 1 \\
43: 1 \\
21: 1 \\
144: 1\end{array}$ \\
\hline $\begin{array}{l}\text { S. aureus } \\
\text { S. aureus + B. fragilis } \\
\text { S. aureus + E. coli } \\
\text { S. aureus + P. mirabilis }\end{array}$ & $\begin{array}{l}\text { S. aureus (10) } \\
\text { S. aureus (3) } \\
\text { S. aureus (5) } \\
\text { S. aureus (5) }\end{array}$ & $\begin{array}{l}1 \cdot 1 \times 10^{5} \\
1.1 \times 10^{6} \\
2.9 \times 10^{5} \\
2.0 \times 10^{5}\end{array}$ & $\begin{aligned} 47: 1 \\
4: 1 \\
17: 1 \\
25: 1\end{aligned}$ \\
\hline $\begin{array}{l}B . \text { fragilis }+E . \text { coli } \\
B . \text { fragilis }+S . \text { aureus }\end{array}$ & $\begin{array}{l}\text { B. fragilis (2) } \\
\text { B. fragilis (2) }\end{array}$ & $\begin{array}{l}2 \cdot 1 \times 10^{5} \\
4 \cdot 3 \times 10^{5}\end{array}$ & $\begin{array}{l}24: 1 \\
12: 1\end{array}$ \\
\hline
\end{tabular}

* Geometric mean concentration $/ 5 \times 10^{6}$ leucocytes. 
Table II. Bacterial killing by abscess-derived leucocytes

\begin{tabular}{|c|c|c|c|c|}
\hline \multirow[b]{2}{*}{ Abscess induced by } & \multicolumn{4}{|c|}{ Change in viability (mean $\log _{10} \pm \mathrm{SDcfu} / \mathrm{ml}$ ) of organism } \\
\hline & Species & $\begin{array}{c}\text { Engulfed in vitro } \\
\text { (number of experi- } \\
\text { ments) }\end{array}$ & $\begin{array}{c}\text { Phagocytosed in vitro } \\
\text { (number of experi- } \\
\text { ments) }\end{array}$ & p value \\
\hline $\begin{array}{l}P . \text { mirabilis } \\
P . \text { mirabilis }+B . \text { fragilis } \\
P . \text { mirabilis }+E . \text { coli } \\
P . \text { mirabilis }+S . \text { aureus }\end{array}$ & $\begin{array}{l}\text { P.m } \\
\text { P.m } \\
\text { P.m } \\
\text { P.m }\end{array}$ & $\begin{array}{l}-0.4 \pm 0.1(4)^{*} \\
-0.1 \pm 0.8(4) \\
-0.4 \pm 0.4(6) \\
-0.5 \pm 0.4(5)\end{array}$ & $\begin{array}{l}-1 \cdot 6 \pm 0.4(4) \\
-1.5 \pm 0.4(6) \\
-1 \cdot 5 \pm 0.2(5) \\
-1 \cdot 4 \pm 0.5(5)\end{array}$ & $\begin{array}{l}p<0.01 \\
p<0.01 \\
p<0.001 \\
p<0.02\end{array}$ \\
\hline $\begin{array}{l}E . \text { coli } \\
E . \text { coli }+B . \text { fragilis } \\
E . \text { coli }+P . \text { mirabilis } \\
E . \text { coli }+S . \text { aureus }\end{array}$ & $\begin{array}{l}\text { E.c } \\
\text { E.c } \\
\text { E.c } \\
\text { E.c }\end{array}$ & $\begin{array}{l}-0.5 \pm 0.2(5) \\
-0.2 \pm 0.3(6) \\
-0.2 \pm 0.3(6) \\
-0.5 \pm 0.3(5)\end{array}$ & $\begin{array}{l}-0.9 \pm 0.2(4) \\
-0.8 \pm 0.4(7) \\
-0.9 \pm 0.2(6) \\
-0.9 \pm 0.0(3)\end{array}$ & $\begin{array}{l}p<0.02 \\
p<0.02 \\
p<0.001 \\
p<0.05\end{array}$ \\
\hline $\begin{array}{l}\text { S. aureus } \\
\text { S. aureus }+B . \text { fragilis } \\
\text { S. aureus }+E . \text { coli } \\
\text { S. aureus }+P . \text { mirabilis }\end{array}$ & $\begin{array}{l}\text { S.a } \\
\text { S.a } \\
\text { S.a } \\
\text { S.a }\end{array}$ & $\begin{array}{l}-0.6 \pm 0.2(10) \\
-0.3 \pm 0.2(3) \\
-0.4 \pm 0.2(5) \\
-0.5 \pm 0.2(5)\end{array}$ & $\begin{array}{l}-0.6 \pm 0 \cdot 1(9) \\
-0.4 \quad(1) \\
-0.4 \pm 0 \cdot 2(3) \\
-0.3 \pm 0 \cdot 2(5)\end{array}$ & $\begin{array}{l}\text { NS } \\
\text { NS } \\
\text { NS }\end{array}$ \\
\hline
\end{tabular}

P.m, P. mirabilis; E.c, E. coli; S.a, S. aureus.

NS, not significant.

Table III. Phagocytic killing by peritoneal exudate neutrophils of bacteria isolated directly from abscesses

\begin{tabular}{|c|c|c|c|}
\hline \multirow[t]{2}{*}{ Bacteria added* } & \multirow[t]{2}{*}{ Source of bacteria } & \multicolumn{2}{|c|}{$\begin{array}{l}\text { Change in viability } \\
\left(\log _{10} \mathrm{cfu} / \mathrm{ml}\right) \\
\text { in presence of }\end{array}$} \\
\hline & & No serum & NMS $2 \%$ \\
\hline $\begin{array}{l}P . \text { mirabilis } \\
4 \times 10^{6} \\
4 \times 10^{6} \\
1 \times 10^{6}\end{array}$ & $\begin{array}{l}\text { TSB culture } \\
\text { Abscess (extracellular) } \\
\text { Abscess (intracellular) }\end{array}$ & $\begin{array}{l}+0.4 \\
-0.2 \\
+0.2\end{array}$ & $\begin{array}{l}-2.9 \\
-1.6 \\
-0.5\end{array}$ \\
\hline $\begin{array}{l}P . \text { mirabilis }(1: 5 \\
8 \times 10^{5} \\
8 \times 10^{5} \\
2 \times 10^{5}\end{array}$ & $\begin{array}{l}\text { of above suspensions) } \\
\text { TSB culture } \\
\text { Abscess (extracellular) } \\
\text { Abscess (intracellular) }\end{array}$ & $\begin{array}{l}+0.3 \\
-0.4 \\
-0.1\end{array}$ & $\begin{array}{l}-2 \cdot 9 \\
-1 \cdot 8 \\
-1 \cdot 1\end{array}$ \\
\hline $\begin{array}{l}\text { E. coli } \\
8 \times 10^{6} \\
3 \times 10^{6} \\
4 \times 10^{6}\end{array}$ & $\begin{array}{l}\text { TSB culture } \\
\text { Abscess (extracellular) } \\
\text { Abscess (intracellular) }\end{array}$ & $\begin{array}{l}\text { ND } \\
\text { ND } \\
\text { ND }\end{array}$ & $\begin{array}{l}-3.0 \\
-1.9 \\
-1.6\end{array}$ \\
\hline $\begin{array}{l}\text { E. coli }(1: 5 \text { of abc } \\
2 \times 10^{6} \\
6 \times 10^{5} \\
8 \times 10^{5}\end{array}$ & $\begin{array}{l}\text { ove suspensions) } \\
\text { TSB culture } \\
\text { Abscess (extracellular) } \\
\text { Abscess (intracellular) }\end{array}$ & $\begin{array}{l}\text { ND } \\
\text { ND } \\
\text { ND }\end{array}$ & $\begin{array}{l}-3 \cdot 1 \\
-2 \cdot 3 \\
-1 \cdot 9\end{array}$ \\
\hline
\end{tabular}

ND, not done.

* The likely numbers of abscess-derived bacteria (to determine the appropriate dilutions of the preparations of intracellular and extracellular bacteria) were determined by assay of abscesses from the same group on the day preceding this experiment. Intracellular organisms were released by sonication.

\section{Expression of cell-surface receptors on abscess- derived neutrophils}

We have shown previously that extracellular serum can stimulate the intracellular bactericidal processes of murine neutrophils, and that this is mediated principally via CR $3 .{ }^{10}$ We tested the hypothesis that the diminished intracellular killing in vitro of organisms phagocytosed in vivo by abscess neutrophils might be explained by a lack of $C R 3$ on the neutrophils that would preclude them from responding to serum in vitro. We determined by flow cytometry that, in the population of abscess-derived neutrophils, there was no evidence for a subpopulation that did not express CR3 or Fc $\gamma$ RII. Furthermore, the fluorescence profiles of abscess-derived neutrophils that had been incubated with NIMP-R10 MAbs (anti-CR3) were compared with the profiles of similarly-treated neutrophils from peritoneal exudates and peripheral blood of normal mice. The expression of CR3 by abscess-derived 
neutrophils was approximately five-fold greater than by peripheral blood neutrophils, and that of peritoneal exudate neutrophils two- to three-fold greater than peripheral blood (fig. 1).

\section{Serum dependence of intracellular killing in vitro of bacteria phagocytosed in the abscess by abscess neutrophils}

Intracellular killing by murine peritoneal exudate neutrophils requires the continued presence of extracellular serum. ${ }^{10}$ Therefore, we examined the requirement of neutrophils derived from abscesses induced by $S$. aureus, $P$. mirabilis and a mixture of the two, for extracellular serum for the killing in vitro of organisms that had been engulfed in the abscess. We found that serum was required (table IV).

\section{Role of CR3 on abscess neutrophils in phagocytic killing of bacteria}

Phagocytic killing of NMS-opsonised $P$. mirabilis by peritoneal exudate cells can be inhibited by prior incubation of the neutrophils with MAb to CR3. ${ }^{10}$

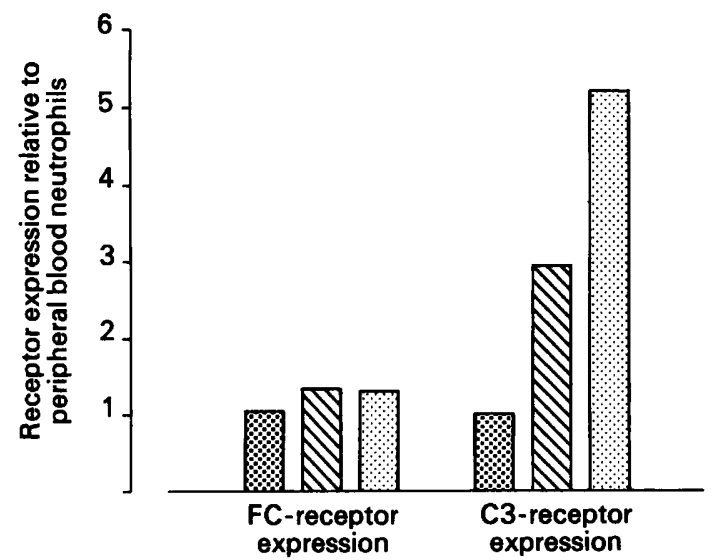

Fig. 1. Fc $\gamma$ RII and CR3 expression on neutrophils from peripheral

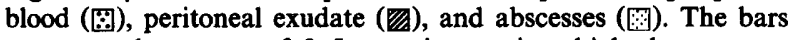
represent the means of 2-5 experiments in which the receptor expression was quantified by the channel of modal fluorescence intensity, and expressed as a proportion of the modal fluorescence of peripheral blood neutrophils. The MAb used to determine CR3 expression was NIMP-R10.

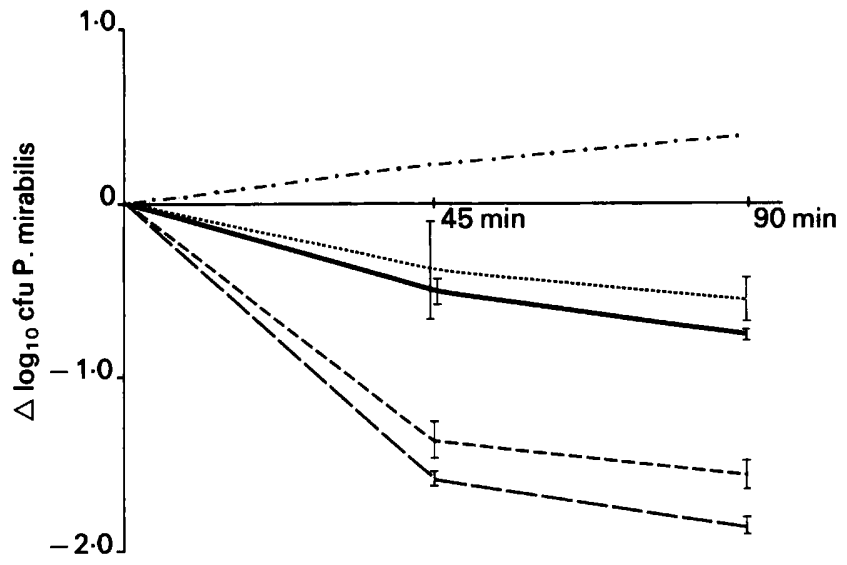

Fig. 2. Effect of incubation of abscess-derived leucocytes with MAbs to either Fc $\gamma$ RII or CR3 on the ability of those cells to phagocytose and kill NMS-opsonised $P$. mirabilis in vitro. The abscesses were induced by a mixture of $\boldsymbol{B}$. fragilis, $\boldsymbol{E}$. coli and bran. The MAbs NIMP-R10 and M1/70 bind to CR3, and $2.4 \mathrm{G} 2$ binds to Fc $\gamma$ RII. P. mirabilis was treated as follows:,-- abscess cells, no MAb; - - - , abscess cells, $2 \cdot 4 \mathrm{G} 2$; — abscess cells, M1/ $70 ; \ldots .$. abscess cells, NIMP-R10; - . - - , no cells, no MAb (control).

Therefore, we examined the effect of pre-incubation for $30 \mathrm{~min}$ of abscess neutrophils with MAb before addition to bactericidal assays. The neutrophils were derived from abscesses induced by $\boldsymbol{B}$. fragilis, $E$. coli and bran; the organism added to the phagocytic assays was $P$. mirabilis. MAb to CR3, but not to Fc $\gamma$ RII, significantly inhibited the bactericidal activity of abscess neutrophils for $P$. mirabilis (fig. 2).

\section{Discussion}

In a previous report, we established that abscessderived neutrophils were functional, being able to phagocytose and kill bacteria in the presence of serum in vitro, yet showing, by comparison, diminished bactericidal activity towards gram-negative bacteria they had phagocytosed in the abscess and contained intracellularly. ${ }^{5}$ In this report, we confirm these findings with a larger range of abscesses (table II). The finding that the gram-negative bacteria isolated directly, without subculture, from abscesses are sus-

Table IV. Serum requirement for intracellular killing by abscess neutrophils

\begin{tabular}{|c|c|c|c|c|}
\hline \multirow[b]{2}{*}{ Abscess induced by } & \multirow[b]{2}{*}{ Organism } & \multicolumn{2}{|c|}{$\begin{array}{l}\text { Change of viability } \\
\left(\text { mean* } \log _{10} \pm \text { SD cfu/ml) }\right. \\
\text { of organism with }\end{array}$} & \multirow[b]{2}{*}{$p$ value } \\
\hline & & NMS $10 \%$ & no serum & \\
\hline $\begin{array}{l}\text { S. aureus only } \\
P . \text { mirabilis only } \\
\text { S. aureus }+P \text {. mirabilis }\end{array}$ & $\begin{array}{l}\text { S. aureus } \\
\text { P. mirabilis } \\
\text { S. aureus } \\
\text { P. mirabilis }\end{array}$ & $\begin{array}{l}-0.5 \pm 0.2 \\
-0.3 \dagger \\
-0.5 \pm 0.2 \\
-0.8 \pm 0.2\end{array}$ & $\begin{array}{c}0.0 \pm 0.3 \\
0.8 \dagger \\
-0.2 \pm 0.2 \\
0.2 \pm 0.3\end{array}$ & $\begin{array}{c}\mathrm{p}<0.01 \\
\ldots \\
\mathrm{p}<0.02 \\
\mathrm{p}<0.001\end{array}$ \\
\hline
\end{tabular}

* Mean of 6-9 experiments.

$\dagger$ Mean of two experiments. 
ceptible to phagocytosis and killing by peritoneal exudate neutrophils (table III) indicates that the abscess-associated organisms are not intrinsically resistant to intracellular killing. Furthermore, we showed that intracellular killing by abscess-derived neutrophils required extracellular serum (table IV), that abscess-derived neutrophils expressed CR3 (fig. 1), and that these receptors were functional (fig. 2).

The neutrophils were obtained by stirring minced abscesses in phosphate-buffered saline. The majority of bacteria in the resultant suspensions were extracellular. However, the neutrophils with intracellular bacteria were separated from the extracellular bacteria by centrifugation on discontinuous density gradients of Percoll and subsequent washing, a procedure we have shown previously to minimise extracellular bacteria in mixtures of bacteria and phagocytosing neutrophils. ${ }^{6}$

Neither $E$. coli nor $P$. mirabilis, when isolated directly, without subculture, from abscesses, were sufficiently opsonised in, or altered by, the abscess environment to be susceptible to killing by peritoneal exudate neutrophils in the absence of serum (table III). However, both extracellular and intracellular abscess-derived bacteria were killed by neutrophils in the presence of serum, albeit less efficiently than logphase organisms taken from broth culture. This may have been because the abscess-derived bacteria were in stationary growth phase and were less susceptible to intracellular killing mechanisms, ${ }^{15}$ but the diminished susceptibility was not sufficient to account, alone, for the poor intracellular killing of organisms engulfed in vivo seen with abscess-derived neutrophils (table II).

Although the structure of the experiments did not allow the statistical analysis of such a comparison and the magnitude of the differences was small, it was of interest to note that the least intracellular killing of the facultative bacteria engulfed in the abscess was found when $B$. fragilis was included in the inoculum (table II). Further experiments are needed to determine the reproducibility of this observation, but it is consistent with the finding that organisms such as $B$. fragilis can inhibit the bactericidal activity of neutrophils ${ }^{4}$ an activity which may relate to the production of succinic acid by $B$. fragilis. ${ }^{16}$ It should be emphasised, nevertheless, that the poor bactericidal activity of abscess neutrophils towards bacteria engulfed within the abscess did not require the presence of $B$. fragilis in the abscess-inducing inoculum.

The complement receptor CR3 plays an important role in the phagocytic killing of bacteria by murine neutrophils. Using an assay to measure intracellular killing in the absence of continuing phagocytosis, ${ }^{8}$ we found that blocking the neutrophil CR3 with the MAb NIMP-R10 significantly reduced NMS-stimulated intracellular killing. ${ }^{10}$ We tested the hypothesis that the diminished killing of bacteria engulfed in vivo by abscess neutrophils might be explained by the existence of a subpopulation of cells that contained the bacteria, but did not express CR3, and were, therefore, unresponsive to the influence of extracellular serum in vitro. Not only was such a population not detected, but the population of abscess-derived neutrophils showed enhanced CR3 expression compared with peritoneal exudate neutrophils, which themselves showed enhanced CR3 expression compared with peripheral blood neutrophils (fig. 1). No marked differences in Fc $\gamma$ RII expression were nrted. That the CR3 on abscess neutrophils were functional was shown by the ability of anti-CR3 MAb to inhibit the bactericidal activity of abscess leucocytes against NMS-opsonised bacteria (fig. 2). The bactericidal activity of abscess neutrophils against gram-negative organisms that had been engulfed in vivo, although diminished compared with killing of organisms engulfed in vitro, required serum, as did killing of the gram-positive organism, $S$. aureus (table IV). This finding is consistent with reports of a requirement for extracellular serum for killing of intracellular bacteria by mouse peritoneal exudate neutrophils, ${ }^{8,10}$ by mouse macrophages, ${ }^{17}$ and by human granulocytes. ${ }^{18}$

Purification procedures may increase CR3 expression. ${ }^{19}$ However, this is unlikely to explain the differences noted between neutrophils from abscesses, peritoneal exudate, and peripheral blood. Although there were some differences in the methods used to prepare cell suspensions from the different sources, all suspensions were maintained at $4-10^{\circ} \mathrm{C}$ during isolation and during the NIMP-R10 fluorescent antibody binding studies, and all preparations were fractionated on Percoll density gradients and resuspended after washing in MPBS. Therefore, it is likely that the differences in CR3 expression were a reflection of the inflammatory status of the site from which the cells were taken. The increase in CR3 expression on activated murine cells is in agreement with findings with human cells. ${ }^{19,20}$

The diminished killing of bacteria within abscess neutrophils subsequently incubated in vitro may reflect the ability of bacteria to persist within abscesses. This is not explained by lack of expression of cell surface receptors or ability to respond to extracellular serum factors, nor by selection of bacteria resistant to intracellular killing. As the minority of neutrophils from abscesses contain viable intracellular bacteria (table I), it may reflect depleted intracellular killing mechanisms in those neutrophils, or result from the phagocytosis of organisms under conditions in the abscess which are possibly suboptimal for subsequent killing (e.g., poor opsonin availability, lowered $\mathrm{pH}$, $\mathrm{Eh}, \mathrm{pO}_{2}$, etc). Alternatively, it may reflect as yet uncharacterised bacterial virulence factors. Nevertheless, sequestration of bacteria within poorly bactericidal, but otherwise viable, neutrophils may allow the organisms to persist at the site of infection.

This work was supported by grants from the National Health and Medical Research Council of Australia, the Flinders Medical Centre Research Foundation, and the Flinders University Research Budget. 


\section{References}

1. Dunn DL, Simmons RL. The role of anaerobic bacteria in intra-abdominal infections. Rev Infect Dis 1984; 6 Suppl 1: S139-S146.

2. Nulsen MF, Finlay-Jones JJ, Skinner JM, McDonald PJ. Intraabdominal abscess formation in mice: quantitative studies on bacteria and abscess-potentiating agents. $B r J$ Exp Pathol 1983; 64: 345-353.

3. Onderdonk AB, Bartlett JG, Louie T, Sullivan-Seigler N, Gorbach SL. Microbial synergy in experimental intraabdominal abscess. Infect Immun 1976; 13: 22-26.

4. Ingham HR, Sisson PR, Tharagonnet $D$, Selkon JB, Codd AA Inhibition of phagocytosis in vitro by obligate anaerobes. Lancet 1977; 2: 1252-1254.

5. Hart PH, Spencer LK, Nulsen MF, McDonald PJ, FinlayJones JJ. Neutrophil activity in abscess-bearing mice: comparative studies with neutrophils isolated from peripheral blood, elicited peritoneal exudates, and abscesses. Infect Immun 1986; 51: 936-941.

6. Finlay-Jones JJ, Hill NL, Nulsen MF, Pruul H, McDonald PJ. Opsonins in normal mouse serum for the phagocytic killing of Proteus mirabilis by murine neutrophils. Br J Exp Pathol 1984; 65: 711-718.

7. Sheridan JW, Finlay-Jones JJ. Studies on a fractionated murine fibrosarcoma: a reproducible method for the cautious and a caution for the unwary. J Cell Physiol 1977; 90: 535-552.

8. Hart PH, Spencer LK, McDonald PJ, Finlay-Jones JJ. Evaluation of intracellular killing of bacteria by enriched populations of mouse peritoneal exudate neutrophils. Aust J Exp Biol Med Sci 1985; 63: 361-370.

9. Ulmer AJ, Flad HD. Discontinuous density gradient separation of human mononuclear leucocytes using Percoll as gradient medium. J Immunol Methods 1979; 30: 1-10.

10. Hart PH, Spencer LK, Nikoloutsopoulos A et al. Role of cell surface receptors in the regulation of intracellular killing of bacteria by murine peritoneal exudate neutrophils. Infect Immun 1986; 52: 245-251.
11. López AF, Battye FL, Vadas MA. Fc receptors on mouse neutrophils and eosinophils: antigenic characteristics, isotype specificity and relative cell membrane density measured by flow cytometry. Immunology 1985; 55: 125133.

12. Unkeless JC. Characterization of a monoclonal antibody directed against mouse macrophage and lymphocyte $\mathrm{Fc}$ receptors. J Exp Med 1979; 150: 580-596.

13. López AF, Burns GF, Stanley IJ. Epitope diversity of monoclonal antibodies revealed by cross-species reactivity. Mol Immunol 1984; 21: 371-374.

14. Beller DI, Springer TA, Schreiber RB. Anti-Mac-1 selectively inhibits the mouse and human type 3 complement receptor. J Exp Med 1982; 156: 1000-1009.

15. Rest RF, Cooney MH, Spitznagel JK. Susceptibility of lipopolysaccharide mutants to the bactericidal action of human neutrophil lysosomal fractions. Infect Immun 1977; 16: $145-151$.

16. Rotstein OD, Nasmith PE, Grinstein S. The Bacteroides byproduct succinic acid inhibits neutrophil respiratory burst by reducing intracellular pH. Infect Immun 1987; 55: 864 870.

17. Leijh PCJ, van Zwet TL, van Furth R. Extracellular stimulation by serum proteins required for maximal intracellular killing of micro-organisms by mouse peritoneal macrophages. Infect Immun 1984; 46: 754-758.

18. Leijh PCJ, van den Barselaar MT, Daha MR, van Furth R. Participation of immunoglobulins and complement components in the intracellular killing of Staphylococcus aureus and Escherichia coli by human granulocytes. Infect Immun 1981; 33: 714-724.

19. Fearon DT, Collins LA. Increased expression of C3b receptors on polymorphonuclear leukocytes induced by chemotactic factors and by purification procedures. J Immunol 1983; 130: $370-375$.

20. Kay AB, Glass EJ, Salter D McG. Leucoattractants enhance complement receptors on human phagocytic cells. Clin Exp Immunol 1979; 38: 294-299. 